\title{
PREFERENCES FOR THE SEX OF OFFSPRING AND DEMOGRAPHIC BEHAVIOR IN EIGHTEENTH- AND NINETEENTH-CENTURY GERMANY: AN EXAMINATION OF EVIDENCE FROM VILLAGE GENEALOGIES*
}

\author{
John Knodel and Susan De Vos**
}

\section{Introduction}

A preference for sons, or for more sons than daughters, transcends mere idiosyncracy to be one of the most universal of culture traits. Evidence of such a preference has been found almost everywhere the subject has been studied, including the United States, Europe, Asia, and Africa (see Williamson, 1976, for an extensive survey of the literature to date). In many societies a preference for sons is deeply rooted in religious beliefs and custom, inheritance law, and family structure.

Preference for the sex of children can have significant impact on either fertility or mortality behavior, and may frustrate many goals of current population policy. For example, sex preference can inhibit

*An earlier version of this paper was presented at the 1979 Annual Meetings of the Population Association of America in Philadelphia, Pa., April 25-27.

The authors are grateful to L. C. Coombs for helpful comments during the course of their research. Part of the research on which this paper is based was sponsored by Grant 1-R01-HD10178-01 from the $\mathrm{Na}$ tional Institutes of Health.

**John Knodel is an associate professor in the Department of Sociology at the University of Michigan as well as a research associate at the Population Studies Center, also at the University of Michigan.

Susan De Vos is a doctoral candidate in the sociology program at the University of Michigan. the adoption of contraception, thereby affecting the average family size and hence the rate of natural increase; it can contribute to higher infant and child mortality among the less preferred sex. Sex preference is also intimately connected with women's position in society and may be either a consequence of or an indicator of sexual stratification.

Did a preference for sons exist in Europe's past, and if so, did that preference have an impact on demographic behavior? Most studies of sex preference refer to modern-day populations and focus on the existence of attitudes rather than on their demographic impact per se (see Williamson, 1976; Coombs, 1978). There is a small but growing body of literature on the subject by demographers, some detecting its influence on demographic behavior while others do not (e.g., Freedman and Coombs, 1974; Goody, 1976a; Ram Gupta, 1975; Heer and Wu, 1975; Pakrasi and Halder, 1971; and Repetto, 1972).

Sex preference attitudes in Europe's past have yet to be studied systematically on the basis of either qualitative or quantitative sources. The curious researcher may glean information on sex preference from discussions of inheritance law, female status, family structure, or infanticide (see Goody, 1976a; Riley, 1968; Shorter, 1975; Segalen, 1975; Sullerot, 1974; Coleman, 
1974; Kellum, 1974; Kennedy, 1973; Langer, 1974; Ring, 1979; Trexler, 1973; and Helmholz, 1975). However, the often theoretical discussion leaves questions about just what sex preference pattern might be expected. Goody, for one (1976a: 3 ), argues that parents tended to see daughters as burdens on the family fortunes in dowry societies such as existed throughout much of Europe. Moreover, males were more valued than females in "heavy plough" societies including those of Europe because the male work role was a dominant one. On the other hand, daughters could still serve important functions. A daughter's marriage could be used to bind interfamilial relationships; daughters were needed to help with the "women's work" which men simply would not do. Even where inheritance rules in Europe favored sons, daughters served as residual heirs and typically did so in preference to more distant male relatives (Goody, 1976b:10). If a daughter were to inherit the family farm or business because there were no male heirs, a son-in-law could "marry in," thus assuring the parents their maintenance in old age. What sex preference pattern, if any should one expect given such customs and role relationships?

Statistical evidence concerning the impact of sex preference on demographic behavior is particularly scanty and must be evaluated warily. One potential source of statistical evidence, the burgeoning number of historical demographic studies based on family reconstitution, has rarely been used to investigate the potential impact of sex preference. The present study is an at tempt to remedy this. We hope this study will inspire, not only other historical demographic studies of sex preference, but, even more importantly, qualitative studies which would provide a firmer knowledge of the broader context for demographic behavior.

\section{Sources, Settings, and Methods}

The present analysis focuses on the experience of twelve German village populations (one, Herbolzheim, has the legal status of a small town), and is based on data from village genealogies (Ortssippenbücher), a source unique to Germany. Unlike most genealogies which trace vital events of a particular family line regardless of where the various branches may have moved, village genealogies encompass all families that ever resided in a particular village. They are limited to the events recorded in the local records, particularly the parish and civil registers, and do not follow families that move away from the village. The data are in the form of reconstituted histories of the vital events experienced by individual couples and thus provide information on the dates of birth, marriage, and death of the couple as well as their children (see also Imhof, 1977).

As in the case of all studies based on family reconstitution data, not every couple has a complete set of information, since vital events occurring outside the village are generally missing; only a selected proportion of families from the village genealogies can be used in any particular demographic analysis. Since the data sets used in the present study were developed for a larger project focusing on fertility, for the sake of economy only those families appropriate for an analysis of fertility were processed. The rules for selecting these families from the genealogies are described in some detail elsewhere (Knodel, 1978). The basic strategy was to select for analysis those families reasonably assumed to be "under observation" during their entire marital reproductive span, provided that the wife's date of birth is also known (at least approximately). Mortality results in the present analysis are also derived from this selection of cases and thus are based on a more restrictive sample than 
would have been necessary had the focus of the broader project been more general.

Wherever possible, we included couples that married between 1700 and 1899 in our analysis, although for several villages couples married in the early decades of the eighteenth century are excluded because of obvious deficiencies in the source material. Reproductive histories of couples married from 1900 on are excluded, but not births occurring after 1899 to couples married before $1900 .{ }^{1}$ Thus the time period covered by the study does extend into the early part of the twentieth century except for one village (Werdum) whose genealogy is based on records only up to 1900 .

Descriptive information about the sample villages has been presented elsewhere (Knodel, 1979). They are located in five different states or regions: Baden (Grafenhausen and Herbolzheim); Württemburg (Öschelbronn); Bavaria (Anhausen, Gabelbach, and Kreuth); Waldeck (Brausen, Höringhausen, Massenhausen, and Vasbeck); Ostfriesland (Middels and Werdum). The two villages in Baden and the three in Bavaria are Catholic, while the others are Protestant. All have small pop-

\footnotetext{
'The decision not to include couples married from 1900 and after was made for two reasons. First, information on the death dates of spouses is often lacking for such couples, and this information is essential for determining whether or not the couple is in observation during their entire reproductive span. Second, by stopping with couples married before 1900 , we largely eliminate problems of interpreting individual reproductive histories which could result from disruptions associated with two World Wars. The number of children in each village upon which most of the calculations in the study are based (all except Tables 5 and 8 ) are as follows:

\begin{tabular}{lr} 
Grafenhausen & 5,438 \\
Herbolzheim & 10,078 \\
Öschelbronn & 4,541 \\
3 Bavarian Villages (1800-99) & 2,157 \\
4 Waldeck Villages & 8,351 \\
Werdum & 5,109 \\
Middels & 3,227 \\
\multicolumn{1}{l}{ Total } & 38,901
\end{tabular}
}

ulations. They represent at least a moderate range of mortality and nuptiality conditions (judging from child mortality and age at marriage) and also show some diversity with respect to occupational distributions (as indicated by the distribution of husbands with occupations given in the genealogy). The three Bavarian villages are in areas where long standing traditions are believed largely to proscribe breast feeding (see Knodel and van de Walle, 1967). These three Bavarian villages, as well as the four villages from Waldeck, have been combined into single data sets to avoid problems associated with small numbers of cases. ${ }^{2}$

While we do not claim that our collection of twelve villages represents a random sample of the rural population of eighteenth- and nineteenth-century Germany, they at least span a reasonable range of regional, demographic, and socio-economic diversity and should provide an interesting variety of settings to explore possible behavioral responses to a preference for the sex of offspring.

We do not have sufficient information about the social, cultural, and economic conditions in our specific villages to enable us to speculate with confidence what they imply for sex preferences, or, if such preferences existed, how they might affect fertility behavior. Nonetheless, in planning our analysis, we reason that most families,

\footnotetext{
${ }^{2}$ The four Waldeck villages all come from the same district (Kreis) and are located within 20 kilometers of each other. They also share reasonably similar child mortality levels and average ages at first marriage. Two of the three Bavarian villages are in the same district, while Kreuth is in a different district approximately 100 kilometers away. In addition, it differs in terms of infant mortality and average age at first marriage. The main justification for combining the three villages, other than the small sample size of each taken separately, is the fact that all apparently shared the custom of avoiding breast feeding, a characteristic which can have important demographic significance (Knodel, 1977).
} 
and especially those who had some property, wanted at least one surviving son to support the parents in old age; given the high childhood mortality, this might have led couples to want several sons to insure that at least one survived to adulthood.

Our analysis explores two different lines of evidence. First, we examine the sex ratio at birth and sex differentials in infant and child mortality for evidence of sex-selective infanticide or preferential child care. Second, we examine the reproductive histories of couples for evidence indicative of sex preference.

Attitudinal indications of sex preferences are completely absent from our data set. Thus we rely on behavioral measures which can be derived from reconstituted family histories to indicate the extent and nature of sex preferences in our sample of German villages. While some of the tabulations we examine can only reveal a predominant preference for one sex or the other, other tabulations potentially allow us to distinguish a preference for a balanced sex composition from a son or daughter preference. In either case, however, the tabulations can only reflect a clearly predominant sex preference pattern. In addition, if individual couples differ in their preferences, they may cancel each other out in the aggregate results and not be detected by our approach. Thus the lack of any apparent pattern cannot rule out the possibility that attitudinal preferences exist. Either they are not being transiated into demographic behavior or combine in the aggregate to give the appearance of no behavioral manifestation of preferences for the sex of offspring.

\section{Sex Ratios at Birth}

The sex ratio at birth for non-negroid populations generally falls between 104 and 107 males per 100 females and most frequently is in the 105 to 106 range (Visaria, 1967). For Germany as a whole, the annual sex ratio at birth during the 25 years following 1875 , the first year for which civil registration data are available for the entire country, varies between 105.1 and 105.9, averaging 105.3 for the entire quarter century.

Deviations from this range, when not a result of random fluctuations associated with small numbers of cases, reflect sexselective underreporting of births. Indeed, in historical and contemporary populations where birth registration is poor, it is not unusual to find "distorted" sex ratios at birth (usually showing an excessive predominance of males). Such distortions are generally attributed to the greater impor. tance given to the registration of one sex (usually male) in populations where children of that sex are, for whatever reason, more highly valued (van de Walle, 1974:49-55; Livi-Bacci, 1971:2; United Nations, 1955:19). An unusual predominance of males at birth or among enumerated children in the past for several European populations has also been interpreted as evidence of infanticide by some scholars. They assume that girls would be more likely to fall victim to infanticide and presumably in the case of sex ratios at birth that the victims would escape registration (deMause, 1974:25-29; 1976). A relatively recent and more or less documented case of female selective infanticide is found among the Jhareja, a group living in Western India (Peterson, 1976:67).

The sex ratios at birth for our sample villages are presented in Table 1. For marriage cohorts in all villages combined, the sex ratio falls right in the middle of the expected 105-106 range. Considerable variation in the sex ratios exists among the separate data sets, especially when broken down further by marriage cohort. Tests of statistical significance, however, suggest these variations are most likely the result of random fluctuation; in no case does the proportion of male births deviate from the hypothetical 105.5 level by more than what we would expect in one out of twenty 
TABLE 1. SEX RATIOS AT BIRTH (MALES PER 100 FEMALES) BY YEAR OF PARENTS' MARRIAGE.

\begin{tabular}{|c|c|c|c|c|c|}
\hline \multirow[b]{2}{*}{ Village } & \multicolumn{5}{|c|}{ Year of Parents' Marriage } \\
\hline & $1700-49$ & $1750-99$ & $1800-49$ & $1850-99$ & Total \\
\hline Grafenhausen & - & $101.9 \mathrm{a}$ & 102.0 & 106.8 & 103.7 \\
\hline Herbolzheim & 113.3 & 103.7 & 112.9 & 105.8 & 108.4 \\
\hline Öschelbronn & $(120.9)$ & $(103.5)$ & 107.6 & 100.4 & 105.7 \\
\hline 4 Bavarian Villages & - & $(103.6)$ & 108.9 & 104.8 & 105.5 \\
\hline 3 Waldeck Villages & 97.7 & 108.1 & 103.8 & 103.2 & 103.8 \\
\hline Werdum & $(102.4)$ & 100.4 & 106.7 & $(117.5)$ & 104.7 \\
\hline Middels & - & $103.4 a$ & $(113.9)$ & 102.9 & 106.2 \\
\hline All Villages Combined & $108.3^{b}$ & $103.4^{\mathrm{C}}$ & 107.8 & 104.8 & 105.6 \\
\hline
\end{tabular}

Notes: None of the sex ratios shown deviate from 105.5 at the .05 level of statistical significance.

Sex ratios shown in parentheses are based on fewer than 1,000 births.

alncludes a small number of births to marriages prior to 1750 .

bIncludes births to marriages prior to 1750 in Grafenhausen and Middels.

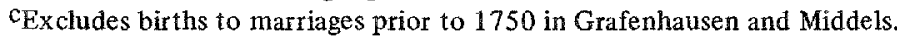

trials on the basis of chance. Moreover, no particular pattern appears to dominate any one of the data sets. In brief, sex ratios at birth in our sample villages appear normal and suggest that if there was underregistration, due to infanticide or other factors, it was apparently not sex selective.

\section{Sex Differentials in Infant and Child Mortality}

While overt infanticide immediately following birth did occur in eighteenth- and nineteenth-century Europe, it was probably limited largely to desperate, unwed mothers and was rare among married couples. But an increasing body of evidence emerging from studies by social historians and others suggests that traditional practices of infant hygiene and and child rearing contributed substantially to high rates of infant and child mortality and led to what is labeled by some as "concealed infanticide" or "infanticide-by-neglect" (Shorter, 1975:168-204; 1978; Langer, 1974; deMause, 1974). ${ }^{3}$ Furthermore,

${ }^{3}$ Since many of these factors are assumed to operate throughout childhood and are not confined to the period of infancy, it would be more correct to refer to filicide than to infanticide. such practices, it may be argued, were a way of limiting family size before knowledge and use of contraception and abortion were widespread (Scrimshaw, 1978; Knodel and van de Walle, 1979). Thus in the absence of birth control, selective neglect could serve not only as an effective substitute but also as a way to adjust the sex composition of the children.

Without judgment of the motivations behind traditional child-care practices, it seems reasonable to argue that if strong preferences existed for one sex over the other, children of the less favored sex would suffer relatively more "neglect," at least in the sense of receiving less or poorer quality food or care. As a result they would experience higher mortality rates. This apparently is the case today in much of South Asia where probably the main factors behind the excessive female mortality at young ages are worse malnutrition and generally preferential treatment of sons (Cassen, 1978:56-57, 114; El-Badry, 1969). Favored treatment of sons is also thought to account for excess mortality among daughters in nineteenth-century Ireland (Kennedy, 1973:51-65). There, girls under age five averaged slightly lower mortality than boys (although not as low as might be 
expected if no favoritism were shown boys), while in later childhood boys had the clear advantage.

One problem with examining sex differentials in infant and child mortality in detecting preferential treatment of one sex over the other is that sex preferences might also affect the completeness of death registration. If differential completeness of death registration is sufficiently pronounced, it could mask the true mortality differentials. It could even give the false impression that children of the more neglected sex experienced relatively lower mortality than children of the preferred sex. While the sex ratios at birth examined in Table 1 helped us rule out the possibility of serious sex differentials in the completeness of birth registration, the determination of the possible existence of differential completeness in death registration is more difficult. At this point we can neither rule out nor substantiate this possibility. ${ }^{4}$

Childhood mortality under age five $\left({ }_{5} q_{0}\right)$ for our sample villages is compared for male and female children in Table 2 over

'The possibility of some minor differential completeness of death registration for boy and girl infants was explored by examining the distribution of infant deaths by age at death. Assuming that the deaths most likely to be omitted are deaths in the first month of life, we can compare the proportion of all infant deaths (i.e., deaths under one year of age) that occur in the first month by sex of infant. Based on Table 3, the results shown below indicate that a very similar proportion of male and female infant deaths occurred in the first month for Grafenhausen, the four Wal-

\begin{tabular}{|c|c|c|c|}
\hline \multicolumn{4}{|c|}{$\begin{array}{c}\text { Deaths under One Month as Proportion } \\
\text { of Deaths under One Year } \\
\end{array}$} \\
\hline Village & Male & Female & Difference \\
\hline Grafenhausen & .473 & .477 & -.004 \\
\hline Herbolzheim & .426 & .396 & .030 \\
\hline Öschelbronn & .531 & .483 & .048 \\
\hline 3 Bavarian Villages & .476 & .428 & .048 \\
\hline 4 Waldeck Villages & .495 & .494 & .001 \\
\hline Werdum & .576 & .531 & .045 \\
\hline Middels & .537 & .541 & -.004 \\
\hline All Villages & .487 & .462 & .025 \\
\hline
\end{tabular}

the period under observation. ${ }^{s}$ The overall picture suggests that girls under five experienced lower mortality in most places at most times, although several exceptions exist. For example, in the Waldeck villages there seems to be a smooth transition from a male to a female advantage over the two centuries.

Lower mortality among young girls does not necessarily imply that female children were given preferential treatment, since a biologically innate female advantage is found in virtually all low mortality populations today (Preston, 1976:121-126). For example, in both East and West Germany around $1970,{ }_{5} \mathrm{q}_{0}$ for females was only 77 . 78 percent as high as for males. Thus while lower male than female mortality strongly suggests favored treatment of sons, lower female mortality might simply reflect no preferential treatment of either sex. In fact, if the female mortality advantage is very small, this could still indicate worse

deck Villages, and Middels, but that in the remain. der, a noticeably lower proportion characterized female rather than male infant deaths. While this might reflect relative underregistration of female death, other factors could also cause the observed differences. For example, the larger average size of males at birth could result in disproportionately higher male neonatal mortality by increasing risks of death associated with parturition. Thus no firm conclusion can be reached. Nevertheless the possibility of differential female death underregistration must be born in mind.

${ }^{5}$ In order to calculate ${ }_{5} q_{0}$, all children for whom a birth date but no death date was given in the families selected from the genealogies for analysis were assumed to survive past age five. Presumably the death dates were missing because they left the village before death. We have in effect assumed in these cases that no child who left the village dies before age five. This assumption seems reasonable since our sample includes only families in which at least one parent's death date was known, generally indicating the family was in the village until the union was broken by death. It seems unlikely that children under age five would leave the village independently of the parents. For a fuller discussion of this point, see footnote 7 in Knodel, 1979. 
TABLE 2. CHILD MORTALITY $\left(5 q_{0}\right)$ BY SEX OF CHILD AND RATIO OF FEMALE TO MALE MORTALITY BY YEAR OF PARENTS' MARRIAGE.

\begin{tabular}{|c|c|c|c|c|c|}
\hline \multirow[b]{2}{*}{ Village } & \multicolumn{5}{|c|}{ Year of Parents' Marriage } \\
\hline & $1700-49$ & $1750-99$ & $1800-49$ & $1850-99$ & Total \\
\hline \multicolumn{6}{|l|}{ Grafenhausen } \\
\hline Males & - & $.379 a$ & .333 & .344 & .349 \\
\hline Females & - & $.356^{\mathrm{a}}$ & .328 & .303 & .326 \\
\hline Ratio & - & $.94^{\mathrm{a}}$ & .98 & .88 & .93 \\
\hline \multicolumn{6}{|l|}{ Herbolzheim } \\
\hline Males & .302 & .358 & .368 & .345 & .350 \\
\hline Females & .321 & .337 & .349 & .317 & .332 \\
\hline Ratio & 1.06 & .94 & .95 & .92 & .95 \\
\hline \multicolumn{6}{|l|}{ Öschelbronn } \\
\hline Males & $(.384)$ & $(.382)$ & .418 & .392 & .396 \\
\hline Females & $(.358)$ & $(.339)$ & .388 & .349 & .359 \\
\hline Ratio & $(.93)$ & $(.89)$ & .93 & .89 & .91 \\
\hline \multicolumn{6}{|c|}{3 Bavarian Villages } \\
\hline Males & - & $(.409)$ & $(.393)$ & .414 & .407 \\
\hline Females & - & (.341) & $(.313)$ & .324 & .326 \\
\hline Ratio & - & $(.83)$ & $(.80)$ & .78 & .80 \\
\hline \multicolumn{6}{|c|}{4 Waldeck Villages } \\
\hline Males & .301 & .320 & .312 & .259 & .295 \\
\hline Females & .308 & .320 & .301 & .229 & .283 \\
\hline Ratio & 1.02 & 1.00 & .96 & .88 & .96 \\
\hline \multicolumn{6}{|l|}{ Werdum } \\
\hline Males & $(.327)$ & .270 & .204 & $(.216)$ & .251 \\
\hline Females & $(.276)$ & .240 & .201 & $(.193)$ & .228 \\
\hline Ratio & .84 & .89 & .99 & .89 & .91 \\
\hline \multicolumn{6}{|l|}{ Middels } \\
\hline Males & - & $(.224)^{\mathrm{a}}$ & .190 & .181 & .194 \\
\hline Females & - & $(.176)^{a}$ & $(.159)$ & .164 & .165 \\
\hline Ratio & - & $(.79)^{\mathrm{a}}$ & $(.84)$ & .91 & .85 \\
\hline \multicolumn{6}{|l|}{ All Villages } \\
\hline Males & $.317^{b}$ & $.285^{\mathrm{c}}$ & .322 & .315 & .323 \\
\hline Females & $.309^{b}$ & $.240^{\mathrm{C}}$ & .302 & .279 & .297 \\
\hline Ratio & $.97 \mathrm{~b}$ & $.84^{\mathrm{C}}$ & .94 & .89 & .92 \\
\hline
\end{tabular}

Notes: Results include both live and stillbirths.

Values of ${ }_{5} q_{0}$ in parentheses are based on fewer than 500 cases. Values of male-female ratios in parentheses indicate that either the ${ }_{5} q$ o values for either males or females or both were based on fewer than 500 cases.

aIncludes children born to marriages prior to 1750 .

bIncludes children born to marriages prior to 1750 in Grafenhausen and Middels.

cExcludes children born to marriages prior to 1750 in Grafenhausen and Middels.

treatment. The relevant question is whether the female advantage is more or less than might be expected from biological factors alone. Unfortunately, this makes firm judgments difficult.

In his recent study of mortality in modern populations, Preston (1976:121124) finds females to have a greater mortality advantage in low mortality popula- tions than in high mortality populations. In a substantial number of the latter, females actually experience higher death rates than males. The relationship between sex differentials and mortality level is probably due in part to a positive association between level of mortality and the extent of preferential treatment. But there is undoubtedly an important biological as- 
pect to the relationship as well. For example, the importance of relatively sex-neutral infectious diseases increases at higher levels of mortality. Other factors beyond this compositional effect also appear to be at work (Preston 1976:153).

Accordingly, independent of sex discriminatory practices, females should not experience as great a relative advantage in high mortality situations, such as our German villages, as are found in low mortality situations, such as in Germany today. If innate biological factors alone were operative, however, female children still should experience at least some modest advantage. Thus, in rural India where for 1968-69 the female death rate under five exceeded the male death rate by 17 percent (calculated from Cassen, 1978:115), sex discriminatory behavior is apparent. Judging from the ${ }_{5} q_{0}$ values in Table 2 , we do not see clear discriminatory behavior in the German villages. Although some favoritism to sons appears for couples married in the first half of the eighteenth century in Herbolzheim and throughout the eighteenth century in the Waldeck villages, girls under five in general experienced a mortality advantage at least close to what might reasonably be expected in the absence of preferential treatment to children of either sex.

Even in high mortality populations where unequal treatment of sons and daughters is known to exist, only after infancy do females experience a clear mortality disadvantage. This is apparent from relatively recent data from Ceylon, Pakistan, and Bangladesh, and historically in Ireland (El-Badry, 1969; Curlin, Chen, and Hussain, 1975; Kennedy, 1973:59-60). Apparently the innate biological advantage plays a role more important in determining sex differentials during the first year of life than in subsequent childhood years. Boys may be particularly disadvantaged with respect to neo-natal mortality, an important component of overall infant mor- tality (Naeye et al., 1971). Moreover, mortality differences due to discriminatory feeding might be evident only after a child is weaned, since obviously breast milk has the same content whether fed to a boy or a girl. Thus it is important to examine sex differentials in mortality at various ages of infancy and childhood for the German vil. lage populations.

A detailed age breakdown of infant and child mortality is presented in Table 3 . For the villages collectively, female mortality advantage under age five results from an even greater advantage under age one; with a slight advantage between ages one and two and a disadvantage between ages two and five. The combination of a small advantage for girls during the second year of life and a small disadvantage during the next three years equalizes the probability of dying between ages one and five $\left({ }_{4} q_{1}\right)$ for the two sexes. Furthermore, the risk of dying between ages five and fifteen $\left({ }_{10} q_{5}\right)$ was exactly equal for males and females. In infancy, girls show the greatest advantage during the first month of life and the least advantage towards the end of the first year. While the decreasing advantage of girls probably reflects in part the increasing importance of the relatively sex-neutral infectious diseases, the lack of any advantage at all after the second year of life and indeed even a small disadvantage between ages two and five suggests the existence of discriminatory child care practices favoring sons, although only to a modest extent. ${ }^{6}$

${ }^{6}$ In rural Ireland in the nineteenth century, the relative situation for females was considerably worse. For the 1831-1841 decade, for example, the rate of female to male mortality was 0.98 for children age five and under, 1.10 for children age 6-10, and 1.22 for children age 11-15 (Kennedy, 1973:59). For India from 1966-70, females even had a disadvantage under age one. The ratio of female to male mortality was 1.08 as indicated by ${ }_{1} q_{0}, 1.20$ as indicated by ${ }_{4} q_{1}$, and 1.23 as indicated by ${ }_{10} \mathrm{q}_{\mathrm{s}}$ (calculated from Cassen, 1978:116). Even greater female disadvantages in 
TABLE 3. INFANT AND EARLY CHILDHOOD MORTALITY BY SEX OF CHILD AND RATIO OF FEMALE TO MALE MORTALITY.

\begin{tabular}{|c|c|c|c|c|c|c|c|c|c|c|}
\hline \multirow[b]{2}{*}{ Village } & \multirow[b]{2}{*}{190} & \multirow[b]{2}{*}{$4 q_{1}$} & \multirow[b]{2}{*}{1095} & \multicolumn{7}{|c|}{ Probability of Dying between Exact Ages } \\
\hline & & & & $\begin{array}{c}0 \& 1 \\
\text { Month }\end{array}$ & $\begin{array}{c}1 \& 3 \\
\text { Months }\end{array}$ & $\begin{array}{c}3 \& 6 \\
\text { Months }\end{array}$ & $\begin{array}{r}6 \& 9 \\
\text { Months }\end{array}$ & $\begin{array}{l}9 \& 12 \\
\text { Months } \\
\end{array}$ & $\begin{array}{l}1 \& 2 \\
\text { Years } \\
\end{array}$ & $\begin{array}{l}2 \& 5 \\
\text { Years } \\
\end{array}$ \\
\hline \multicolumn{11}{|c|}{$\overline{\text { Grafenhausen }}$} \\
\hline Boys & .262 & .118 & .058 & .124 & .065 & .048 & .034 & .022 & .055 & .066 \\
\hline Girls & .235 & .119 & .047 & .112 & .051 & .038 & .035 & .022 & .053 & .070 \\
\hline Ratio & .90 & 1.01 & .81 & .90 & .78 & .79 & 1.03 & 1.04 & .96 & 1.05 \\
\hline \multicolumn{11}{|c|}{ Herbolzheim } \\
\hline Boys & .237 & .148 & .056 & .101 & .050 & .053 & .031 & .027 & .070 & .084 \\
\hline Girls & .207 & .157 & .060 & .082 & .046 & .041 & .030 & .027 & .068 & .096 \\
\hline .. Ratio & .87 & 1.06 & 1.06 & .81 & .93 & .77 & .97 & 1.01 & .98 & 1.14 \\
\hline \multicolumn{11}{|c|}{ Öschelbromn } \\
\hline Boys & .311 & .124 & .055 & .165 & .055 & .041 & .054 & .037 & .061 & .067 \\
\hline Girls & .265 & .128 & .048 & .128 & .058 & .047 & .035 & .028 & .059 & .074 \\
\hline Ratio & .85 & 1.03 & .88 & .77 & 1.06 & 1.14 & .64 & .74 & .96 & 1.11 \\
\hline \multicolumn{11}{|l|}{3 Bav. Vil. } \\
\hline Boys & .357 & .076 & .036 & .170 & .089 & .084 & .038 & .022 & .032 & .044 \\
\hline Girls & .278 & .058 & .039 & .119 & .055 & .069 & .032 & .018 & .031 & .027 \\
\hline Ratio & .78 & .76 & 1.08 & .72 & .63 & .82 & .92 & .89 & .99 & .61 \\
\hline \multicolumn{11}{|c|}{4 Wald. Vil. } \\
\hline Boys & .186 & .133 & .063 & .092 & .029 & .026 & .027 & .026 & .062 & .076 \\
\hline Girls & .166 & .140 & .066 & .082 & .027 & .025 & .020 & .023 & .061 & .084 \\
\hline Ratio & .89 & 1.05 & 1.05 & .89 & .93 & .96 & .74 & .89 & .98 & 1.11 \\
\hline \multicolumn{11}{|l|}{ Werdum } \\
\hline Boys & .158 & .110 & .069 & .091 & .029 & .022 & .013 & .011 & .047 & .066 \\
\hline Girls & .147 & .094 & .072 & .078 & .030 & .020 & .012 & .015 & .041 & .056 \\
\hline Ratio & .93 & .85 & 1.03 & .85 & 1.03 & .93 & .89 & 1.32 & .87 & .85 \\
\hline \multicolumn{11}{|l|}{ Middels } \\
\hline Boys & .136 & .068 & .044 & .073 & .023 & .017 & .014 & .014 & .031 & .037 \\
\hline Girls & .109 & .064 & .047 & .059 & .015 & .010 & .017 & .011 & .022 & .043 \\
\hline Ratio & .80 & .94 & 1.08 & .81 & .64 & .56 & 1.23 & .79 & .71 & 1.14 \\
\hline \multicolumn{11}{|c|}{ All Villages } \\
\hline Boys & .226 & .122 & .058 & .110 & .045 & .039 & .029 & .023 & .056 & .069 \\
\hline Girls & .197 & .123 & .058 & .091 & .040 & .034 & .025 & .022 & .054 & .073 \\
\hline Ratio & .87 & 1.01 & 1.00 & .83 & .88 & .86 & .87 & .94 & .95 & 1.06 \\
\hline
\end{tabular}

Notes: Calculations of $1 q_{0}$ and the probability of dying between exact ages 0 and 1 month include stillbirths. Results refer to children born to marriages between 1700-1899 with the following exceptions: Grafenhausen refers to 1740-1 899; 3 Bavarian Villages refer to 1800-1899. Children bom to marriages prior to 1800 in the 3 Bavarian villages were excluded from the present table, because a large number of child deaths prior to 1800 in two of the villages were not recorded directly in the death register but indicated instead by marking a cross in the birth register next to the name of the child without indicating the date of death. This creates problems for allocating these deaths by age at death. The small number of such cases among children born to marriages after 1800 in the Bavarian villages are assumed to be infant deaths (i.e., occurring before age 1) and were distributed by age during the first year of life in the same proportions as infant deaths of known age. The ratio of female to male mortality was calculated before rounding mortality rates as shown.

One potentially important influence on infant mortality in the past is the type of infant feeding. Results from a number of

childhood mortality after age one are reported for the Matlab Thana area of Bangladesh where from 1966-71 female mortality exceeded male mortality by

studies in Europe and the U.S. done at the end of the nineteenth century and the first

41 percent between ages $1-4,18$ percent between ages 5-9, and 38 percent between ages 10-14 (calculated from Curlin, Chen and Hussain, 1975:23). 
decades of the twentieth century clearly indicate that breast fed infants experienced far lower death rates than artificially fed infants; infants on mixed feeding regimes occupied an intermediate position (Knodel, 1977). Throughout the early months of life, infants who were weaned typically experienced higher mortality than those still being breast fed (Knodel and Kintner, 1977). Thus the variation in the age pattern of sex differentials in mortality among the different villages found in Table 3 might be explained by differences in breast feeding customs. Also, the pronounced female advantage during the first half year of life in the Bavarian villages suggests that the artificial feeding practices did not discriminate against daughters in Bavaria where we have reason to presume breast feeding was rare. 7

Differential age at weaning between girl and boy infants could contribute to sex differentials in mortality. This appears to be the case among Guatemalan Indians where "the cultural tendency to favor males... is apparently expressed by breast feeding male infants for a longer period than females (Cowgill and Hutchinson, 1963:97)."

Direct data on the proportion of infants breast fed or the average duration of breast feeding by the infant's sex is not available for our sample villages. Nevertheless, it is possible to test indirectly for sex differentials in this respect by comparing the length of birth intervals following the birth of sons and daughters. Since breast feeding prolongs the period of postpartum amenorrhea and thus delays the next pregnancy, in the absence of birth control the length of birth interval tends to

${ }^{7}$ Statistics for all of Bavaria show a similar strong female advantage in infant mortality. For example, from $1835 / 36-1868 / 69$, the infant mortality rate for the entire kingdom averaged 41.2 per 100 live births for males and 35.7 for females (Lee, 1977:67). be directly proportional to the duration of breast feeding. This is the explanation usually offered to account for the often observed relationship in natural fertility populations between the age at death of infants born at the onset of birth intervals and the length of the intervals. Even during periods of family limitation, provided birth control was practiced primarily to stop childbearing rather than to space children, the length of birth intervals should reflect the extent of breast feeding.

A comparison of the average interval following the birth of boys and of girls is provided in Table 4. It has been shown elsewhere (Knodel, 1979) that even after the onset of family limitation in our sample villages, there is little evidence of increased birth spacing, at least during the period under observation. Therefore, results for the entire time span covered by our analysis are aggregated for each village without separating out the period before and after the onset of family limitation. Since there are sex differentials in infant mortality, and since infant deaths typically shorten birth intervals by curtailing breast feeding, thus shortening the period of postpartum amenorrhea, the average interval following births of children surviving to at least age one are shown in addition to all intervals.

The results in Table 4 clearly indicate only minimal, statistically non-significant differences in the subsequent birth intervals according to the sex of the child. While we might expect to find little difference in birth intervals following births of boys and girls in Bavaria where breast feeding was rare, it is noteworthy that even in Werdum and Middels-both located in Ostfriesland, an area noted for prolonged breastfeeding - there is also no indication that boys were breast fed to a later age than girls. Apparently sons and daughters were breast fed equally throughout Germany. This agrees with direct evidence from Berlin, where census tabulations 
TABLE 4. AVERAGE INTERVAL (IN MONTHS) BETWEEN BIRTHS ACCORDING TO THE SEX OF THE CHLD BORN AT THE ONSET OF THE INTERVAL, FOR INTERVALS FOLLOWING ALL BIRTHS AND INTERVALS FOLLOWING BIRTHS SURVIVING TO AT LEAST AGE ONE.

\begin{tabular}{|c|c|c|c|c|c|c|}
\hline \multirow[b]{2}{*}{ Villages } & \multicolumn{3}{|c|}{$\begin{array}{l}\text { Intervals Following } \\
\text { All Births of }\end{array}$} & \multicolumn{3}{|c|}{$\begin{array}{l}\text { Intervals Following } \\
\text { Surviving Births of }\end{array}$} \\
\hline & Boys & Girls & Difference & Boys & Girls & Difference ${ }^{a}$ \\
\hline Grafenhausen & 28.7 & 28.6 & 0.1 & 30.9 & 30.3 & 0.6 \\
\hline Herbolzheim & 28.0 & 28.4 & -0.4 & 29.9 & 30.0 & -0.1 \\
\hline Öschelbronn & 26.3 & 26.1 & 0.2 & 28.9 & 28.1 & 0.8 \\
\hline 3 Bavarian Villages & 22.8 & 23.2 & -0.4 & 23.8 & 24.2 & -0.4 \\
\hline 4 Waldeck Villages & 31.4 & 31.3 & 0.1 & 33.8 & 33.4 & 0.4 \\
\hline Werdum & 33.4 & 33.2 & 0.2 & 35.4 & 35.3 & 0.1 \\
\hline Middels & 33.9 & 35.0 & -1.1 & 35.7 & 36.8 & -1.1 \\
\hline All Villages & 29.3 & 29.5 & -0.2 & 31.6 & 31.5 & 0.1 \\
\hline
\end{tabular}

Notes: Intervals refer to confinements and thus include still births but exclude intervals between multiple births.

Results refer to children born to marriages between 1700-1899 with the following exceptions: Grafenhausen refers to $1740-1899 ; 3$ Bavarian Villages refer to $1750-1899$.

aNone of the differences are statistically significant at the .05 level.

from 1885 to 1905 indicate essentially equal proportions of breast-fed boys and girls. ${ }^{8}$

\section{Reproductive Behavior}

If preferences concerning the sex of children are strong, they should be evident in the reproductive behavior of couples provided that fertility is consciously controlled. Given the secular decline of marital fertility on the national level in Germany only from the latter part of the nineteenth century onward (Knodel, 1974), it is important to determine the extent of fertility control in the sample villages during the period under observation and to limit the analysis of fertility behavior to villages and periods characterized by at least some significant amount of deliberate fertility control within marriage.

${ }^{8}$ For example, in 1885 , 55.0 percent of male infants were reported as breast fed compared to 55.5 percent of females; in 1905 , the proportion of both male and female infants breast fed was 31 percent. Thus in the intervening 20 years, although the practice of breast feeding declined substantially, it did so equally with regard to sons and daughters (calculations from the Berlin censuses were kindly provided by Hallie Kintner).
Table 5 summarizes some of the evidence on fertility trends and family limitation for the sample villages. The index of marital fertility $\left(\mathbb{I}_{\mathrm{g}}^{\prime}\right)$ is a modified version of the Ig index developed by Ansley Coale (1969). Like the original index, $\mathrm{I}_{\mathrm{g}}^{\prime}$ indicates the ratio of the fertility of the specified population to the highest marital fertility on reliable record, that of Hutterites married in the 1920s. But it does so after standardizing for the age pattern of fecundity directly rather than indirectly. ${ }^{9}$

There is substantial variation in the level of fertility across villages as measured by $\mathbf{I}_{\mathbf{g}}^{\mathbf{g}}$. The high fertility in the Bavarian villages is undoubtedly associated with the relative absence of prolonged breast feeding, while the lower fertility in Werdum and Middels probably reflects the much longer breast feeding characteristic of Ost-

${ }^{9}$ While the original version of $I_{g}$ incorporated an indirect standardization for age patterns of fecundity within the childbearing span, the modified version employed in the present study takes advantage of the availability of age-specific marital fertility rates for the populations under observation. It incorporates a direct standardization using the number of married women by five-year age groups for Germany as a whole as recorded in the 1871 census. 
friesland (Röse, 1905; Bluhm, 1912). The fertility decline, so distinctly evident at the end of the nineteenth century in national and provincial level statistics on married fertility (Knodel, 1974), is far from uniform on the village level. In the four Waldeck villages the fertility index drops suddenly among women married in the last quarter of the nineteenth century; in Grafenhausen, a steady decline appears to have begun around the turn of the nineteenth century; and in Öschelbronn, no sign at all of a fertility decline appears, only a generally rising marital fertility.

For the present study, evicience of the extent of family limitation is of greater interest than levels or trends in fertility. For this purpose we turn to the index of fertil- ity control $(m)$ developed by Coale and Trussell (1974 and 1978). The index is constructed to equal 0 if the shape of the fertility schedule in question is identical to that of a standard natural fertility schedule (i.e., a schedule representing fertility in the absence of family limitation). Since $m$ is determined entirely by the age pattern of marital fertility rates, it is independent of the level of fertility. The faster marital fertility falls with age, the greater the fertility control implied and the higher the value of the $m$ index. Small differences in the value of $m$, however, are not necessarily meaningful indications of differences in the extent of family limitation. Even among the ten empirical fertility schedules which served as the basis for determining

TABLE 5. INDEX OF MARITAL FERTILITY (I'g) AND INDEX OF FERTILITY CONTROL $(m)$ BY YEAR OF MARRIAGE.

\begin{tabular}{|c|c|c|c|c|c|c|}
\hline \multirow[b]{2}{*}{ Villages } & \multicolumn{6}{|c|}{ Year of Marriage } \\
\hline & $1700-49$ & $1750 \cdot 99$ & $1800-24$ & $1825-49$ & $1850-74$ & $1875-99$ \\
\hline \multicolumn{7}{|l|}{ Grafenhausen } \\
\hline$I^{\prime} g$ & $-\mathbf{a}$ & .867 & .800 & .754 & .671 & .539 \\
\hline$m$ & $-\mathbf{a}$ & .05 & .01 & .34 & .62 & .78 \\
\hline \multicolumn{7}{|l|}{ Herbolzheim } \\
\hline$I_{g}^{\prime}$ & .834 & .824 & .799 & .723 & .747 & .738 \\
\hline..$m^{5}$ & -.11 & -.11 & .10 & .37 & .51 & .67 \\
\hline \multicolumn{7}{|l|}{ Öschelbronn } \\
\hline$I$ 'g & .717 & .772 & .849 & .959 & .912 & .976 \\
\hline$m$ & .28 & .18 & .28 & .17 & .13 & .27 \\
\hline \multicolumn{7}{|c|}{3 Bavarian Villages } \\
\hline$I^{\prime} g$ & $-a$ & .989 & .897 & .898 & 1.011 & .896 \\
\hline$m$ & $-a$ & -.04 & .22 & .08 & .28 & .41 \\
\hline \multicolumn{7}{|c|}{4 Waldeck Villages } \\
\hline$I^{\prime} g$ & .699 & .769 & .765 & .831 & .851 & .697 \\
\hline$m$ & .00 & -.05 & .02 & -.02 & .03 & .44 \\
\hline \multicolumn{7}{|l|}{ Werdum } \\
\hline$I !_{\mathrm{g}}$ & .738 & .728 & .602 & .668 & .665 & $-\mathbf{a}$ \\
\hline$m$ & .03 & .23 & .25 & .29 & $(.31)$ & $-\mathbf{a}$ \\
\hline \multicolumn{7}{|l|}{ Middels } \\
\hline I'g & $-\mathbf{a}$ & .702 & .642 & .704 & .633 & .637 \\
\hline$m$ & $-a$ & .04 & .10 & .12 & .21 & .46 \\
\hline
\end{tabular}

Notes: Results in this table are based on couples for which both the wedding and the end of the marriage occurred locally and the date of the end of the marriage is known with certainty.

Values of $m$ shown in italics indicate that the mean square error of the regression used to estimate $m$ exceeded .005 .

The calculations are based on an average of at least 200 married woman-years in each five-year age group between 20 and 44 years of age.

aInsufficient cases. 
the standard shape of natural fertility, the values of $m$ ranged from -.15 to .24 . Modern populations in which contracep. tion is widespread are typically characterized by $m$ values well over 1.00 .

The low values of $m$ characterizing couples married during the eighteenth century in all of the villages, and during much of the nineteenth century in some, suggest that little if any family limitation was exercised at this time. The shift from natural fertility to family limitation is reasonably clear in some villages but more ambiguous in others. In the four Waldeck villages and to a lesser extent in Middels, substantial and more or less abrupt in. creases in $m$ characterize the fertility control of women married in the last quarter of the nineteenth century. This almost certainly reflects a departure from natural fertility or from much lower levels of family limitation practice. In Grafenhausen the unusually early decline of marital fertility is accompanied by a very sharp rise in the value of $m$ for couples married in the second quarter of the nineteenth century. In neighboring Herbolzheim, an even earlier trend toward increased family limitation is apparent from the increasing value of $m$ for each successive marriage cohort throughout the nineteenth century. Indeed, in spite of the leveling off of marital fertility in the second half of the century in Herbolzheim, $m$ continues to rise. In the remaining villages a departure from natural fertility, or at least from a low level of deliberate control, is difficult to identify whether or when it occurred.

Because of the importance of focusing on couples practicing family limitation in an analysis of the influence of sex preferences on fertility, we limit consideration to Grafenhausen, Herbolzheim, the four Waldeck villages, and Middels. In each case we examine the evidence separately for couples married before and after the apparent onset or increase of family limi- tation. ${ }^{10}$ In addition, when the number of cases permits, we give special scrutiny to couples who stopped childbearing before the wife reached age 38 , since such couples were more likely to be the ones deliberately limiting their fertility. It should be borne in mind that even in these villages the extent of family limitation practiced during the period under observation was still quite modest compared to modern populations which have more or less completed the fertility transition. The methods of fertility control assumed to be available to couples were far from perfect (e.g., coitus interruptus) or were associated with high psychic costs (e.g., abstinence).

Before our own analysis of evidence of sex preference among the couples living in the German villages, it is worth calling attention to the findings of studies using a similar approach with data for contemporary populations. In Korea, for example, where there has long been a traditional preference for sons and where the recent modal ideal family is two sons and one daughter, Park (1978) found that the bearing and spacing of children after the third birth were strongly influenced by the sex composition of the first three children once birth control had been widely dis-

${ }^{10}$ Additional evidence of family limitation for these villages is apparent in the decline in the average age at last birth during the period under observation for women whose marriages lasted at least through their forty-fifth birthday. In both Grafenhausen and Herbolzheim the age at last birth was three years younger for women married from $182 \overline{5}$ through 1899, compared to women married before 1825. Women married 1875-99 were three years younger at last birth in Waldeck and two years younger in Middels compared to women married before 1875. For a more detailed analysis of the extent of family limitation in the sample villages, see Knodel, 1978 and 1979. 
seminated through the National Family Planning Program. In addition, the use of birth control in Korea is closely associated with the sex composition of the children already born (Park, 1978:96). In contrast, Repetto (1972) found little or no effect of the sex composition of the family on fertil. ity in Lucknow, Delhi, East Pakistan, or Morocco. This is hardly surprising in the first three cases, since he did not limit consideration to women who practiced birth control and who undoubtedly constitute but a small percentage of the total sample. In the Moroccan sample, however, he did separate past and current contraceptive users from non-users, but obtained conflicting results for the rural and urban samples. In a number of developed countries today, much as in the United States, sex composition has little effect on fertility behavior, presumably because consideration of family size dominates that of the sex composition of offspring (see Freedman and Coombs, 1974).

These divergent findings for contemporary populations should warn us that the manner in which sex preference might affect fertility behavior is complex. This should be especially so in a population, such as the one with which we are dealing, in which mortality was high and in which as a consequence uncertainty about the survival of offspring was great. Furthermore, if discriminating child care practices affected sex preferences following birth, couples relying on practices which, either deliberately or unconsciously, resulted in the death of the newborn might have been less motivated to use family limitation, especially since the costs devolved on different people. In the case of a mortality mechanism, it was largely the mother and the child who bore the cost. In the case of fertility-related selection, where coitus interruptus or abstinence was the primary birth control technique, much of the cost was borne by the husband. Indeed the alternatives are, among other things, undoubtedly associated with the status of women and, indirectly with the very exisstence of sex preference. But infanticide or neglect tended to diminish if not disappear with fertility control, so the potential compensatory effect of one method on the use of the other is probably limited.

Given the high infant and child mortality prevalent in our sample villages, mortality experience must be incorporated into our measures of fertility, a problem not faced by most researchers looking at contemporary populations. We do this by considering the sex composition not of all children ever born, but of children who survive at least to age five. We recognize that this is an imperfect situation for two reasons. First, some children who survive to age five still die before adulthood. But mortality in later childhood is low compared to infant and early childhood mortality. The older a child at death, the greater the chance the mother will be past her reproductive span and the less chance she will be able to adjust her fertility accordingly. Second, couples presumably act on their subjective assessment of mortality risks for their children which are only imperfectly reflected in our objective measures. Thus, if couples are concerned with the number of sons who will be alive to support them in old age, their subjective assessment of the sex composition of surviving children may be at considerable variance with the sex composition of children who survive to age five. Discrepancies between objective and subjective assessments may be particularly acute during the periods of mortality decline that characterized most of the sample villages toward the end of the nineteenth century (see Knodel, 1979). Despite these problems, limiting consideration to children surviving to age five should be a reasonably effective and operationally simple way of improving our analysis, in comparison with the more usual approach which considers all live births. 

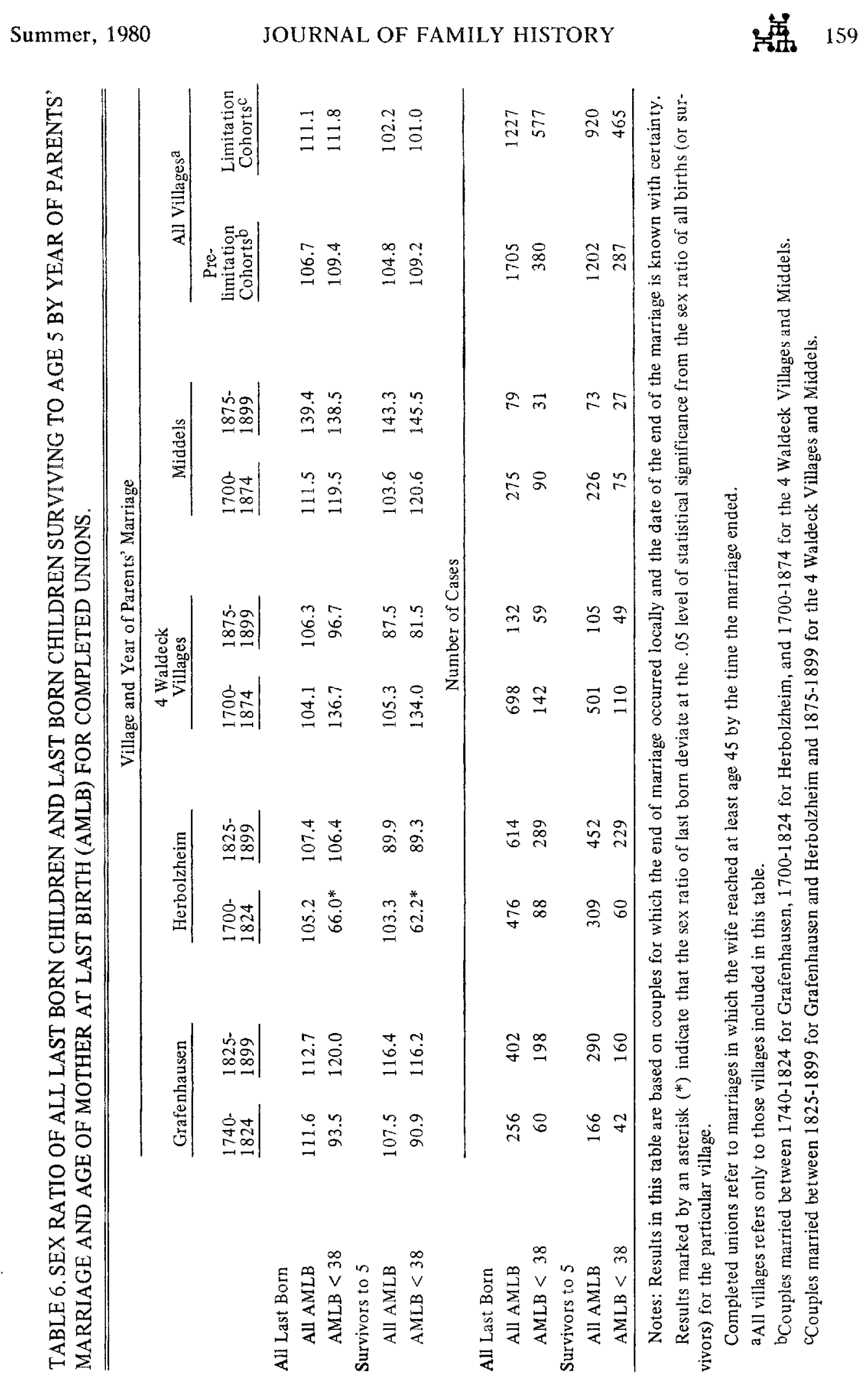
Given these caveats, we now turn to the results of our efforts to detect differential fertility control in our subset of sample village populations. Our first approach examines the sex ratio of last born children. We reason that if couples preferred sons to daughters, they would be more likely to stop childbearing if the last child born was a boy. Under such circumstances, the sex ratio of surviving last births should be significantly higher than if sex-specific control were not exercised. Table 6 tests this hypothesis. While we are primarily interested in the period of family limitation in this and the following tables, pre-limitation figures are shown for purposes of comparison.

Contrary to what we could expect if son preference were affecting fertility behavior, we find in Table 6 no systematic pattern of high sex ratios among the last born across all villages. While in Grafenhausen and Middels sex ratios of all last born as well as survivors to five are high during the period of family limitation, the opposite is true in Herbolzheim and the Waldeck villages. Only two sex ratios deviated from that of all births or survivors by an amount greater than that indicated by the .05 level of statistical significance; and both of the ratios, in the village of Herbolzheim, contradict what we expected and during the pre-limitation period. Furthermore, limiting consideration to couples in which the wife had her last birth before age 38 is as likely to decrease as to increase the sex ratio. From this initial search then, either our measurement technique is insensitive to a preference for sons, or if it existed such a preference did not affect fertility behavior.

A second way in which we might detect preference-caused fertility behavior is by measuring the length of the last interval following the births of children surviving to age five by sex of the surviving children. If couples wanted to prevent the childbearing after the birth of a boy and if the avail- able contraceptive methods were less than perfect, these attempts would often result in postponing a later and often last birth rather than preventing another birth altogether. Under such circumstances, we would expect to find a longer average last interval after boy births. This would be reinforced if male babies were favored by longer periods of breast feeding, although, as already shown, that does not seem to be the case in our German village populations. By limiting ourselves to the cases in which children survived to age five, we allow for the fact that parents presumably desire surviving children rather than merely live births. Moreover, we control for the higher likelihood that boy infants die which could shorten the average birth interval after the birth of male babies.

The results in Table 7 enable us to evaluate this hypothesis. In brief, the results are inconclusive. While the relationship between the sex of the penultimate child and the last birth interval during the limitation period is consistent with son-preference in Grafenhausen, the four Waldeck villages, and Middels, the relationship is less so in Herbolzheim. Since Herbolzheim is large relative to the other villages, almost no difference exists in the length of last intervals for the villages combined (48.7 vs. 48.3 ). Still it is suggestive that in both Grafenhausen and Middels the sex ratio of the last born during the limitation period was also disproportionately male.

The sex ratio and birth interval tests have the disadvantage of aggregating all last births or all last birth intervals irrespective of the number of surviving children or the composition of the family. If sex preference existed, and if it influenced fertility behavior, we would expect fertility limitation to reflect the sex composition of all previously born children. The figures in Table 8 attempt to take this into account by showing separately for families, with at least one to four surviving children, parity progression ratios (i.e., the proportion of 
TABLE 7. LAST BIRTH INTERVAL IN MONTHS FOLLOWING BIRTHS OF CHILDREN SURVIVING TO AGE 5 FOR COMPLETED UNIONS BY SEX OF SURVIVING CHILDREN AND YEAR OF PARENTS'MARRIAGE.

\begin{tabular}{|c|c|c|c|c|c|}
\hline \multirow{3}{*}{$\begin{array}{c}\text { Village and Year of } \\
\text { Parents' Marriage }\end{array}$} & \multicolumn{4}{|c|}{ Sex of Surviving Child } & \multirow[b]{3}{*}{ Differenced } \\
\hline & \multicolumn{2}{|c|}{ Boy } & \multicolumn{2}{|l|}{ Gir1 } & \\
\hline & Interval & $\mathrm{N}$ & Interval & $\mathrm{N}$ & \\
\hline \multicolumn{6}{|l|}{ Grafenhausen } \\
\hline $1740-1824$ & 42.8 & 86 & 40.9 & 70 & 1.9 \\
\hline $1825-1899$ & 52.3 & 148 & 49.7 & 132 & 2.6 \\
\hline \multicolumn{6}{|l|}{ Herbolzheim } \\
\hline $1700-1824$ & 41.1 & 145 & 44.5 & 139 & -3.4 \\
\hline $1825-1899$ & 46.5 & 197 & 49.2 & 195 & -2.7 \\
\hline \multicolumn{6}{|l|}{4 Waldeck Villages } \\
\hline $1700-1874$ & 46.1 & 221 & 44.9 & 238 & 1.2 \\
\hline 1875-1899 & 45.8 & 54 & 43.0 & 49 & 2.8 \\
\hline \multicolumn{6}{|l|}{ Middels } \\
\hline $1700-1874$ & 52.0 & 94 & 53.7 & 123 & -1.7 \\
\hline $1875-1899$ & 51.3 & 26 & 45.9 & 40 & 5.4 \\
\hline \multicolumn{6}{|l|}{ All villages ${ }^{a}$} \\
\hline Pre-limitation cohorts $b$ & 45.3 & 546 & 46.2 & 570 & -0.9 \\
\hline Limitation cohorts $\mathrm{c}$ & 48.7 & 425 & 48.3 & 416 & 0.4 \\
\hline
\end{tabular}

Notes: Completed unions refer to marriages in which the wife reached at least age 45 by the time the marriage ended.

a All villages refer only to those villages included in this table.

bCouples married between 1740-1874 for Grafenhausen, 1700-1 824 for Herbolzheim, and 1700-1 874 for the 4 Waldeck Villages and Middels.

cCouples married between 1825-1899 for Grafenhausen and Herbolzheim and 1875-1899 for the 4 Waldeck Villages and Middels.

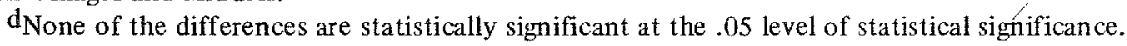

couples continuing to bear children) according to the number of sons already surviving. Results are presented for each village and all villages combined. Because of the small numbers of cases, separate results are only given for couples in which the wife was under age 38 at the time of her last birth for all villages combined.

In general, it is difficult to discern any consistent relationship between sex composition and the probability of having an additional birth across villages or across parities within the same village. In Grafenhausen there seems to be some tendency among the "limitation" cohorts for women with no sons but with at least one, two, or three surviving children to be more likely to continue childbearing than women with sons, although the differences in parity progression ratios are not large. A greater likelihood to continue childbearing among comparable marriage cohorts with no sons but with at least two or three children is also evident in neighboring Herbolzheim. But in both places among women with at least four children, those with less than two sons were less likely to continue than those with three or four. There are several possible reasons for this. Perhaps couples with four children, at least three of which were daughters, wished to stop childbearing rather than risk still another daughter. Alternatively couples with four surviving children may have been more concerned with overall family size than with sex composition, or they may have been among those exercising little deliberate control. Or maybe we are observing largely chance variation since the results are far from statistically significant, even at the .05 level.

If we focus on the combined results for 


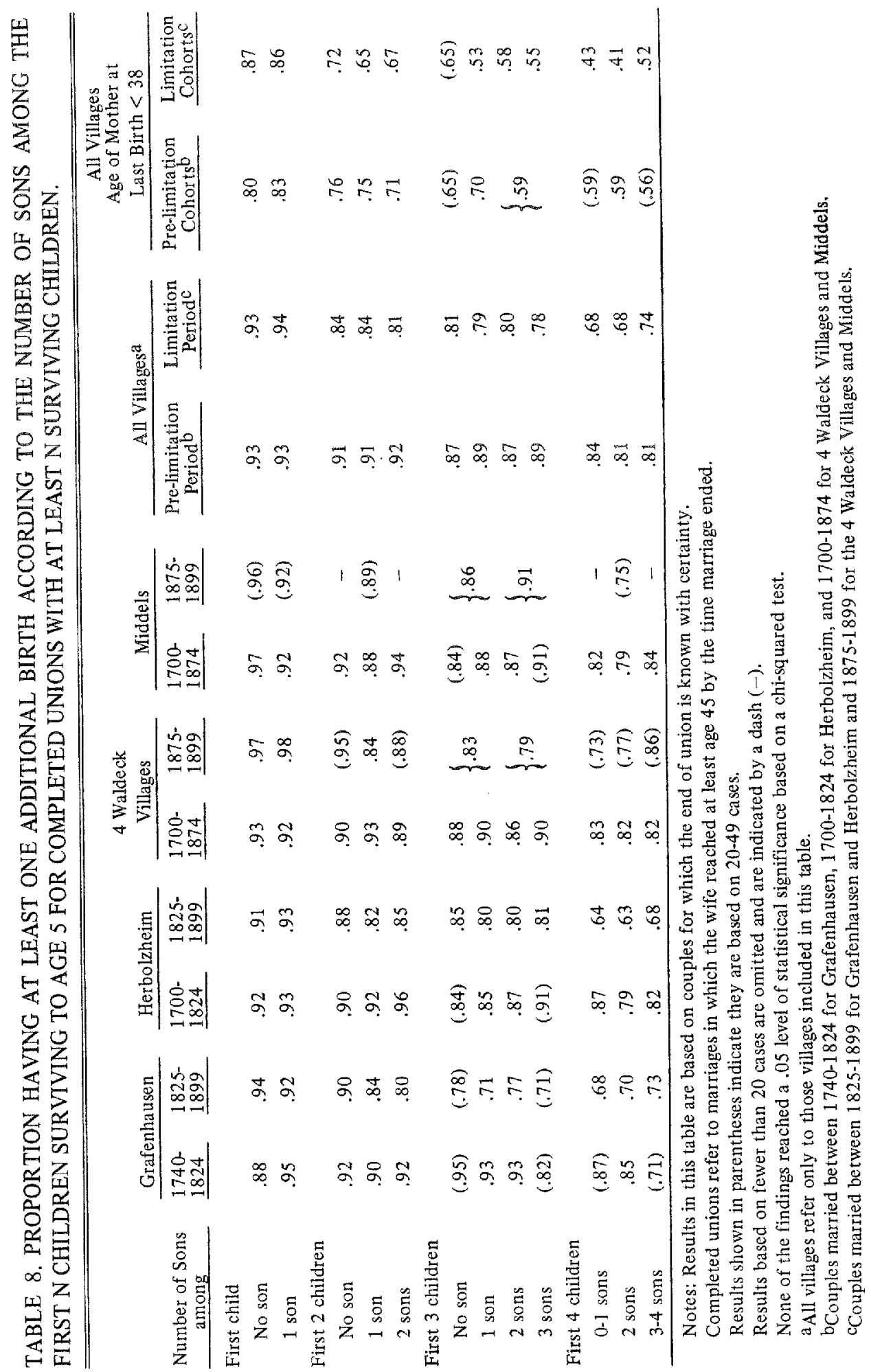


all villages, the similarities in parity progression ratios, not their differences, are the most striking features for both the "prelimitation" and the "limitation" marriage cohorts. Even when we restrict consideration to couples in which the wife was under 38 at the time of last birth, differences remain small and no consistent pattern emerges. Among couples with at least two or three surviving children, those with exactly one son were least likely to continue, perhaps reflecting a desire for one male heir. But again the magnitude of the differences is so small that the results could well be due to chance.

We also examined parity progression ratios for landed peasants since there might be greater concern over the sex composition among couples with farmsteads at stake, at least for the sake of inheritance. The results (not presented) generally showed no greater consistency than for all couples. But one statistically significant result in a direction indicative of a preference for sons did emerge for Grafenhausen. For the "limitation" cohorts, the proportion of peasant couples with at least two surviving children who continued childbearing was clearly associated with the number of sons: 91 percent of those with no sons, 85 percent of those with one son, and 73 percent of those with two sons went on to have additional children. A similar though less pronounced relationship held for peasant couples with at least one child in Grafenhausen, but not with those with at least three or four children. Thus firm conclusions are elusive; at most, the results are suggestive. For example, partible inheritance prevailed in Grafenhausen, so by the nineteenth century, peasant families may have been increasingly concerned about further subdivision. It is noteworthy that peasant couples showed the greatest signs of family limitation at this time (Knodel, 1979).

The use of parity progression ratios to detect sex preferences is admittedly crude.
Methodological and interpretative problems with this approach are discussed in more detail by Freedman and Coombs (1974). In particular, we know that preferences for the sex of children are not the same for all couples in a particular population. Such heterogeneity of sex preferences can only operate to obscure this effect on parity progression ratios, except when they are taken explicitly into account in the analysis. Nevertheless, where there is a strong and predominant pattern of sex preference in combination with substantial family limitation, the expected patterns are reasonably clear. For example, when Park's data for Korea are recombined to form categories comparable to those used in Table 8, large and statistically significant differences are apparent for the period following the introduction of the national family planning program (Park, 1978:98). The lack of clear patterns in our results may be the result of either no strong predominant preference for sex of offspring, inefficient family limitation practices, or both. During the early phases of the fertility transition historically, a substantial proportion of couples may not have been deliberately controlling their fertility or were doing so with only partial success. This would weaken any relationships between fertility and sex composition. Even restricting consideration to women who stop childbearing before age 38 , we may fail to screen out many of the couples who either do not deliberately or successfully practice family limitation. This concern is reinforced by Park's finding that prior to 1965 , when birth control was far less widespread in Korea, there was no significant association between parity progression ratios and sex composition (Park, 1978:98).

\section{Conclusions}

During periods of natural fertility when family limitation was either absent or rare, couples presumably were unable to re- 
spond to their sex preferences by adjusting their subsequent reproductive behavior in accordance with the sex of the children already born. Instead they could directly affect the sex composition of their existing children, either consciously or unconsciously, through differential child care favoring one sex at the expense of the other. In extreme cases, sex selective infanticide could be practiced. Evidence from our sample of German villages for the eighteenth and nineteenth centuries suggests such practices were uncommon. Perhaps some slight preference was shown sons in terms of child care, but there is litthe to indicate extreme preferential treatment.

While the results of our analysis of fertility and sex composition were ambiguous, it seems safe to conclude that they gave no indication of a strong predominant preference for particular combinations of sons and daughters. Of course, much more than consideration of sex of offspring is involved in the desire to limit fertility. For a demographic effect to be evident, sex preference must either work in the same direction as other forces or must be strong enough to dominate them. Thus we emphasize that the absence of a demonstrable demographic effect does not prove an absence of sex preference.

In sum, while our analysis is far from conclusive, it does suggest that preference concerning the sex of children had at most only a weak influence on demographic behavior historically in Germany, at least during the eighteenth and nineteenth centuries. Clearly, more research needs to be done, including far more qualitative analysis, before we can gain a full understanding of differential attitudes towards sons and daughters and their demographic and societal consequences in the past. We hope our present limited effort based on the demographic experience of German village populations will help stimulate greater interest and focus more attention on this underresearched topic.

\section{BIBLIOGRAPTIY}

Bluhm, A

1912 "Stillhäufigheit and Stilldauer." In A. Grotjahn and J. Kaup, eds., Handwörterbuch der sozialen Hygiene, 570-591. Band II. Leipzig: F. C. W. Vogel.

Cassen, R. H.

1978 India: Population, Economy, Society. New York: Holmes and Meier Publishers, Inc.

Coale, Ansley J.

1969 "The Decline of Fertility in Europe from the French Revolution to World War II." In S. J. Behrman, Leslie Corsa, Jr., and Ronald Freedman, eds., Fertility and Family Planning. Ann Arbor: University of Michigan Press.

Coale, Ansley J. and T. James Trussell

1974 "Model Fertility Schedules: Variations in the Age Structure of Childbearing in $\mathrm{Hu}$ man Populations." Population Index 40:185-258. (See also Erratum, Population Index 41:572.)

1978 "A New Procedure for Fitting Optimal Values of the Parameters of a Model Schedule of Marital Fertility Rates." Population Index 44:203-211.

Colemen, Emily

1974 "L'infanticide dans le Haut Moyen Age." Annales: Economies, Sociétés, Civilisations 29:315-335. Reprinted as "Infanticide in the Early Middle Ages." In Susan M. Stuard, ed., Women in Medieval Society, 47.70. Philadelphia: University of Pennsylvania Press, 1976.

Coombs, Lolagene

1977 "Preferences for Sex of Children Among U.S. Couples." Family Planning Perspective 9:259-265.

Coombs, Lolagene C. and Te-Hsiung Sun

1978 "Family Composition Preference in a Developing Culture: The Case of Taiwan, 1973." Population Studies 32:43-64.

Cowgill, Ursula M. and G. E. Hutchinson

1963 "Sex-ratio in Childhood and the Depopulation of the Péten, Guatemala." Human Biology 35:91-103.

Curlin, George T., L. C. Chen, and S. B. Hussain

1975 Demographic Crisis: The Impact of the Bangladesh Civil War (1971) on Births and Deaths in a Rural Area of Bangladesh. Dacca: The Ford Foundation.

deMause, Lloyd, ed.

1974 The History of Childhood. New York: The Psychohistory Press.

1976 "The Formation of the American Personality through Psychospeciation." Journal of Psychohistory (Summer):1-30. 
El-Badry, M. A.

1969 "Higher Female than Male Mortality in Some Countries of South Asia: A Digest." Journal of the American Statistical Association 64: 1234-1244.

Freedman, Ronald and Lolagene C. Coombs

1974 Cross-cultural Comparisons: Data on Two Factors in Fertility Behavior. New York: The Population Council.

Goody, Jack

1976a Sex Preference, Resources and Population. A report of a research project sponsored by the Rockefeller and Ford Foundations and the Ministry of Overseas Development, London.

1976b "Inheritance, Property, and Women: Some Comparative Considerations." In Jack Goody, Joan Thirsk, and E. P. Thompson, Family and Inheritance; Rural Society in Western Europe 1200-1800. Cambridge, England: Cambridge University Press.

Heer, David M. and Hsin-ying Wu

1975 "The Effect of Infant and Child Mortality and Preference for Sons upon Fertility and Family Planning Behavior." In John F. Kantner and Lee McCaffrey, eds., Population and Development in Southeast Asia. Lexington, Mass.: Lexington Books, D. C. Heath and Co.

Helmholz, R. A.

1975 "Infanticide in the Province of Canterbury during the Fifteenth Century." History of Childhood Quarterly 2:379-397.

Imhof, Arthur E.

1977 "Historical Demography and Social History: Possibilities in Germany." Journal of Family History 2:305-332.

Kellum, Barbara A.

1974 "Infanticide in England in the Later Middle Ages." History of Childhood Quarterly 1:367-388

Kennedy, Robert E., Jr.

1973 The Irish Emigration, Marriage, and Fertility. Berkeley: University of California Press.

Knodel, John

1974 The Decline of Fertility in Germany, 18711939. Princeton: Princeton University Press.

1977 "Breast Feeding and Population Growth." Science 198:1111-1115.

1978 "Natural Fertility in Preindustrial Germany." Population Studies 32:481-510.

1979 "From Natural Fertility to Family Limitation: The Onset of Fertility "Transition in a Sample of German Villages." Demography (forthcoming).

Knodel, John and Hallie Kintner

1977 "The Impact of Breast Feeding Patterns on the Biometric Analysis of Infant Mortality." Demography 14:391-409.
Knodel, John and Etienne van de Walle

1967 "Breast Feeding, Fertility, and Infant Mortality: An Analysis of Sone Early German data." Population Studies 21:109-132.

1979 "Lessons from the Past: Policy Implications of Historical Fertility Studies." Population and Development Review 5:217-245.

Langer, William L.

1974 "Infanticide: A Historical Survey." History of Childhood Quarterly 1:354-366.

Lee, W. Robert

1977 Population Growth, Economic Development, and Social Change in Bavaria 17501850. New York: Arno Press, Inc.

Livi-Bacci, Massimo

1971 A Century of Portuguese Fertility. Princeton, N.J.: Princeton University Press.

Naeye, Richard, L. S. Burt, D. L. Wright, W. A. Blane, and D. Tatter

1971 "Neonatal Mortality, The Male Disadvantage." Pediatrics 48:902-906.

Pakrasi, K. and A. Halder

1971 "Sex Ratios and Sex Sequences of Births in India." Journal of Biosocial Science 3:377. 387.

Park, Chai Bin

1978 "The Fourth Korean Child: The Effect of Son Preference on Subsequent Fertility." Journal of Biosocial Science 10:95-106.

Peterson, William

1976 Population. 3rd edition. London: CollierMacmillan, Ltd.

Preston, Samuel $\mathrm{H}$.

1976 Mortality Patterns in National Populations. New York: Academic Press.

Ram Gupta, Sant

1975 "Mortality Patterns in India." In R. B. Chari, ed, Demographic Trends in India, 43-52. New Delhi: O. P. Sharma and R. K. Bhatia.

Repetto, Robert

1972 "Son Preference and Fertility Behavior in Developing Countries." Studies in Family Planning 3:70-75.

Riley, M.

1968 Brought to Bed. New York: A. S. Barnes and Company.

Ring, Richard $\mathrm{R}$.

1979 "Early Medieval Peasant Households in Central Italy." Journal of Family History $4: 2-25$.

Röse, C.

1905 "Die Wichtigkeit der Mutterbrust für die Körperliche und geistige Entwicklung des Menschen." Deutsche Monatsschrift für Zahnheilkunde 23:129-176.

Scrimshaw, Susan C. M.

1978 "Infant Mortality and Behavior in the Regulation of Family Size." Population and 
Development Review 4:383-404.

Segalen, Martine

1975 "Le mariage, lamour et les femmes dans les proverbes populaires français." Ethnologie française 5:119-136.

Shorter, Fdward

1975 The Making of the Modern Family. New York: Basic Books.

1978 The Great Transformation of Mother-Infant Relations, Eighteenth to Twentieth Century. Manuscript.

Smith, Thomas C.

1977 Nakahara: Family Farming and Population in a Japanese Village, 1717-1830. Stanford, California: Stanford University Press.

Sullerot, Evelyne

1974 Woman, Society, and Change. New YorkToronto: McGraw-Hill.

1973 "The Foundlings of Florence, 1395-1455."
Trexler, Richard C. History of Childhood Quarterly 1:259-284.

United Nations

1955 Methods of Appraisal of Quality of Basic Data for Population Estimates. Manual II. Department of Economic and Social Affairs, New York.

van de Walle, Etienne

1974 The Female Population of France in the Nineteenth Century. Princeton, N.J.: Princeton University Press.

Visaria, Pravin $M$.

1967 "Sex Ratio at Birth in Territories with a Relatively Complete Registration." Eugenics Quarterly 14:132-142.

Williamson, Nancy E.

1976 Sons or Daughters. A Cross-Cultural Survey of Parental Preferences. Beverly Hills, California: Sage Publications. 